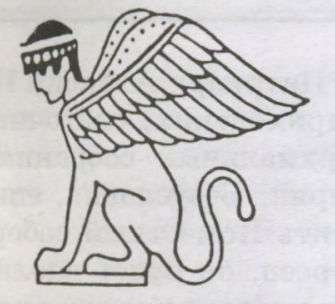

полития

ЗИМА 1997-1998

ПРАВОСЛАВНАЯ ПОЛИТИКА: ТОЧКИ ЗРЕНИЯ

\title{
В.Л. Махнач
}

\section{ПАРАМЕТРЫ ХРИСТИАНСКОЙ ПОЛИТИКИ}

\section{ЦЕРКОВЬ - СУБЪЕКТ ПОЛИТИКИ}

Для древних египтян и древних евреев, персов и римлян, жителей средневекового Кельна и средневекового Новгорода все в жизни начиналось с Веры. На вероисповедание опиралась нравственность, этика, на этику - политика. Лишь совсем недавно возникло и распространилось ложное утверждение: «политика - дело грязное». Так говорят те, кто хотел бы, чтобы люди чистые смирились с грязными политиками, чтобы чистые люди политикой заниматься перестали, оставив ее тем, кто «вынужден» делать за нас "грязное дело». А люди тысячелетиями жили иначе.

"Политика - это прикладная этика», - писал Г.Федотов. Значит, бывает политика нравственная, а бывает безнравственная, "грязная». И если мы утверждаем, что политический лидер, министр или мэр - «грязный политик», так это потому, что действительно этот человек «грязный", а не потому что он мәр или министр.

Есть и другое ложное утверждение, подобное приведенному выше, - дескать Церковь не занимается политикой. Еще как занимается! Есть политика Поместной церкви - в интересах всех христиан данной территории и есть политика Вселенской Церкви - в интересах всех православных христиан, ныне живущих и тех, кто еще будет жить 1 .

24 августа 1917 г. было установлено, что «Церковь Православная не принимает участия в борьбе политических партий». Это само собой разумеетя, ибо политика любой партии - это политика в интересах некоей группы, а политика Церкви - это политика в интересах всего православного народа в полном соответствии с духом знаменитого послания Восточных Патриархов 1848 г.

Православная Церковь такой же субъект меж- дународного права, как и Римско-католическая, хотя и не имеет в своем распоряжении крошечного государства, подобного Ватикану (кстати, и римско-католические нунции представляют не государство Ватикан, а Святой престол).

\section{ЦЕРКОВЬ И ГОСУДАРСТВО}

Российская держава создана Вселенской Церковью. Об этом свидетельствует деятельность святителей Всероссийских, начиная с митрополита Кирилла, современника и друга св. Александра Невского, а также то, как Церковь отклоняла попытки расчленения русского церковного единства, когда не было единства политического. Именно в силу того, что Литва стремилась иметь собственную управляемую "карманную" митрополию, не была тверда в Православии, она не стала оплотом Вселенской Церкви и не основала великого государства. Основала его Москва. А вообще говоря, если бы великие князья литовские со времен Гедимина вели себя несколько иначе, российское государство могло иметь столицей Вильно.

Россия не выбирала себе роль империи. Ее готовили к этому на протяжении XIII-XV столетий: в XIII в. - как союзницу слабеющей Византии, а к концу XIV в., пожалуй, греки уже лучше нас видели, что Константинополь обречен. Готовили Россию как преемницу, которой вручили скипетр вместе с основными, выработанными Церковью и православной государственностью, нормами. Именно тогда мы получили идею симфонии - сосуществования и взаимной поддержки Церкви и православного Государя.

Московским князьям, даже самым прославленным, Церковь не спускала попытки своего устранения от великого дела созидания Российской империи как опоры Вселенского Правосла- 
вия. "Москва - третий Рим» - идея не националистическая, а церковная. Идея преемства по православному имперскому служению. Церковный смысл монархии именно в том, что делает монархию во многом сакральной. Православный царь освящен как своеобразный служитель Церкви.

Вспомним «дело Митяя». Тогда раскольническую попытку создать отдельную от общерусской московскую митрополию возглавил сам великий князь Дмитрий Иванович - будущий Донской герой, Святый благоверный князь, канонизированный в 1988 г. Он возглавил эту попытку и проиграл в столкновении с преподобным Сергием, святителем Киприаном, с теми, кто созидал будущую Россию. И в силу этого ныне он канонизирован и чтим всеми нами. Оказывается, полезно проигрывать, если проигрываешь Церкви.

Монархистом можно быть и вне идеи симфонии. Но тогда в монархии нет ничего священного. Она рассматривается просто как наиболее удобный вид власти, что было известно еще Аристотелю. Особый православный характер монархии вытекает из церковного благословения, а никак не из природы монархической власти. $\mathrm{K}$ сожалению, иным монархистам об этом приходится напоминать. У них не монархия - атрибут церковности, а Церковь - чуть ли не атрибут монархии, что, вообще-то говоря, - язычество. Только став Православным Царством, Россия получила двуглавого орла ${ }^{2}$.

Церковь, будучи основательницей государства, вовсе не привязана к территории этого государства. Территория Российской Церкви не совпадала с территорией СССР. Ее юрисдикция не распространялась на Грузию и Армению, зато действовала за пределами Советского Союза. Тем более не совпадают территории, находящиеся под юрисдикцией Церкви и сегодняшней Российской Федерации.

Как бы не менялась территория нашей страны, она не будет совпадать с территорией Церкви. В конце концов, они не могут совпадать ни у какой церкви ни с каким государством, хотя бы потому, что Церковь продолжается на Небесах и к ней принадлежат умершие христиане. Полагаю, у нас есть основания утверждать, что государство на Небесах не продолжается.

Государство не должно ставить знак равенства между Церковью и иерархией, что любила делать бюрократия советского государства. Для нее Церковь была удобоугнетаемой именно в виде бюрократической организации, где "директор" в силу традиции называется «патриархом", а «заведующие отделами» - «епископами». Осознание неприемлемости такого отношения должно возвращать Церковь к историческим, глубоко укорененным нормам.

Сейчас наша Церковь различает Поместный и Архиерейский соборы. Следовательно, надо возвращаться к нормам Собора 1917-1918 годов, к чему призвал и Святейший Патриарх Алексий II Это означает избрание на приходских, благочин нических и, наконец, епархиальных собрания представителей клира и мирян. Безусловно, епг скопы властны сами составить Поместный собор Состоящий из одних архиереев, он будет вполн каноничным. Но если уж мы различаем два тип Собора (что, кстати, вполне в русской нацио нальной традиции), клириков и мирян долже избирать церковный народ - «хранитель Верв православной". Если же епископы прост «захватили" с собой на Поместный собор кого-т из мирян, то это их свита, и она никого не пред ставляет.

Несомненно, следует восстановить учрежден ный Собором 1917 г. Высший Церковный Совет в котором заседали три епископа из Синода шесть клириков и шесть мирян. Это нужно, ко нечно, не для того, чтобы умалить права (или, в дай Бог, честь и достоинство!) наших архипасты рей, а для того, чтобы заставить государство вес ти диалог именно с православным народом. Еслг есть чиновники, которым господин Президені поручает общаться с церковными инстанциями то должны быть и православные, которым Цер ковь поручает общаться с господином Президев TOM.

Если выстроить иерархию ценностей право: славной политики, то можно обнаружить, чт нация в ней занимает особое положение. Наци - в ответе перед Богом и Вселенской Церковью Государство же - перед нацией. "Монархия дл нации, а не наоборот» - постулирует И.А.ИльиЕ в трактате "О монархии и республике". Грязня толпа может запятнать себя грехом цареубийс ва. Но благородный гнев нации обрушивается в главу государства, изменившего долгу переI Церковью или нацией. Так он обрушился на Ве силия Шуйского и Петра III.

Государство, даже откровенно богоборческое, тем более нынешнее - лицемерно-доброжелателс ное $к$ Церкви, злоупотребляет ее статус «нашей», национальной. Мы должны помниту что для государства, во всяком случае не возгла ляемого в порядке симфонии с Церковью правсд славным государем, мы такие же чужие, ка мормоны или кришнаиты. И даже еще более чр жис, потому что "свои потерпят" - как осмелх ваются по-прежнему полагать бюрократы.

Конечно, государство безбожников не может постичь мистическую природу Церкви как Тел Христова, но социальную природу, как совокуг ность всех христиан данной земли, оно понимат обязано. Православные всегда в проигрыше, когд позволяют оказывать давление на своих иерархон которых миряне все еще плохо защищают. Надн учиться подлинному единению со своими архгд пастырями, ломать бюрократические привычки, чиновников и журналистов воспитывать.

Совершенно очевидно, что президент, міл нистр, мәр или журналист должен обращаться I 
епископу только «Ваше преосвященство», а к священнику - «Ваше преподобие». А «отед такой-то" он может говорить только тогда, когда перед интервью подошел под благословение, из чего вытекает, что он - православный христианин. И тогда батюшка ему действительно "отец", а епископ - «владыка».

\section{ПРАВОВОЕ ПОЛОЖЕНИЕ ЦЕРКВИ}

2 декабря 1917 г. Святой Поместный Собор Православной Российской Церкви издал знаменитое определение о публично-правовом положении Церкви. Его должен знать каждый христианин. Это - закон для русского христианина до тех пор, пока другой Собор его не изменит (сомнительно, правда, чтобы на это кто-нибудь посягнул),

Пункт первый определения утверждает, что «Православная Российская Церковь занимает первенствующее среди других исповеданий публично-правовое положение». В таком первенствуюгем положении, не означающем угнетения иноверцев, православие находится в Греции, ислам - в целом ряде государств.

Пункт третий декларирует, что «постановления, издаваемые Церковью для самой себя, признаются государством имеющими юридическую силу, поскольку ими не нарушаются государственные законы".

Пункт седьмой гласит, что «Глава Российского государства, Министр Исповеданий и Министр Народного Просвещения и Товарищи (заместители) их должны быть православными».

В последующих пунктах говорится:

- об уголовном наказании за поношение Церкви,

- о законной силе церковного брака,

- о полноправии церковных школ,

- о преподавании Закона Божия в гражданских школах для православных детей,

- о запрещении конфискации церковного имущества,

- о беспрепятственном получении прав юридического лица церковными установлениями ${ }^{3}$

Кстати, последнее означает, что власти должны моментально регистрировать не только епархии, приходы и монастыри, но и братства, сестричества, просветительские и миссионерские центры, союзы приходов и т. п.

Как не обратиться тут к двум важнейшим моментам церковной жизни, за которые православным еще придется бороться.

Bo-nервых, возвращение церковных регистрационных книг. Запрещение регистрации Крещения и Брака сегодня выдано за демократическое достижение, поскольку все помнят времена, когда книги просматривались безбожным начальством и крещеных выгоняли с работы. Ныне начальство либо само крестилось, либо пикнуть не смеет, а православные не знают, кто венчан и может быть церковнослужителем или мирским православным начальником, а кто в блуде живет.

Во-вторых, возвращение церковного имущества. Средства массовой информации время от времени раздувают кампании, требуя вернуть Церкви у нее награбленное. Почему-то обычно "награбленными" оказываются иконы из наших музеев, чьи сотрудники погибали в большевистских лагерях, спасая эти иконы... Необходимо не сталкивать во вражде две стороны великой культуры - литургию и музей, - а вернуть все награбленное. Школы и академии, больницы и богадельни, библиотеки и типографии. Все дома и всю землю, принадлежавшие монастырям, епархиям, братствам, приходам. Ведь грабители - не нищие музейные работники, а бюрократическая система государства, сопротивляющаяся возвращению отнятого у Церкви имущества.

\section{ВНУТРЕННЯЯ И ВНЕШНЯЯ БЮРОКРАТИЯ}

Во главе Православной Церкви в любом месте ее земного пребывания стоит епископ. Он - преемник апостолов, возглавитель соборной молитвы всех христиан своей епархии. Прежде всего через его молитву христианин сохраняет единство со всей вселенской Церковью. Более того, в богослужении епископ символизирует Самого Христа. Епископ (по-гречески «блюститель») вероучитель и судья а priori.

Христианин принадлежит к Церкви, покуда сохраняет со своим епископом единение в любви. Не повиновение, не субординацию, а любовь! Отсюда нетрудно видеть, что власть епископа предельно далека от бюрократической. Церковь вообе отторгает бюрократизацию, ибо любовь неформальна.

Епископ-викарий предстоятелем не является, он пользуется уважением, подобающим любому епископу, но не обладает соответствующей властью. Даже если какой-либо отдел Патриархии (структурное подразделение, обязанное обслуживать всю Церковь) возглавляет епархиальный архиерей, то он в своей епархии - вероучитель и судья, а в отделе - клерк.

Коммунистический режим немало потрудился, дабы епископ поменьше общался с православным народом, а побольше - с государственными чиновниками. Трудится и нынешний режим, кое в чем преуспевая не хуже коммунистов.

Скажем, участвовала православная общественность в решении вопросов восстановления Храма Христа Спасителя? Обсуждала проекты, решала, кто будет восстанавливать? Нет. Поэтому восстановлением занимаются в основном безбожники, искажающие замысел архитектора К.Тона.

А как обстояло дело с чудовищным комплексом на Поклонной горе? Все решали между собой 
правительственные чиновники и чиновники церковные. А ведь администрация с православной точки зрения - не более чем категория обслуживающего персонала. Тем более администрация церковная, чья единственная функция - претворить в жизнь соборную волю Церкви.

Поскольку русские вообще не любят бюрократов и бюрократию, общение дерковных чиновников с безбожниками за спиной церковного народа, а тем более попытки какого-нибудь «отдела»говорить от имени Церкви могут в перспективе вызвать сколь угодно жесткую реакцию. Христианина ведь ничто не обязывает к единению в любви с клерком, в каком бы сане оный не пребывал.

Есть и еще одно соображение: христианин вправе разорвать отношения с епископом лишь в случае принадлежности последнего к ереси. Слава Богу, пока такого не происходило. Однако есть для христианина («верного» - такое наше первоначальное самоназвание, сохраненное в богослужении) более тяжкое преступление: отступничество, Иудин грех. В этом случае бесспорно право (оно же и долг!) христиан выволакивать отступника за бороду из храма, что бывало в истории Церкви.

Крайне осложнена жизнь Церкви фактическим отсутствием церковного суда. Опять порочный круг: Писание запрещает православ- ному вообще судиться мирским судом со своим собратом, а епископского суда не существует. И этот круг предстоит преодолеть: суд Церкви - строго епископская прерогатива, но не инициатива его совершения. Христианин или группа христиан вправе требовать суда, а уклоняющегося от своего долга архиерея считать отступником.

Жизнь Церкви в России затруднена застарелой чисто русской болезнью - малочисленностью епархий. Нетрудно подсчитать, что если бы мы подходили к важнейшему вопросу о численности паствы с традиционно греческой меркой (или с «прогрессивной» римско-католической), в СССР должно было быть порядка 500 кафедр, в РФ порядка 400. На нынешней пятикратной недостаточности бюрократия не без успеха паразитирует: бюрократы в рясах стремятся втиснуться между архиереем и церковным народом, а бюрократы в пиджаках - инкорпорировать архиерея в местную «знать».

Справедливости ради отметим, что за время нынешнего патриаршества количество епархий нашей Поместной Церкви возросло почти вдвое. Однако и ныне есть субъекты Федерации без собственных епархий; и ни один субъект не обладает несколькими церковными округами. Между тем очевидно, что такая перенаселенная область, как Московская, должна включать несколько епархий.

Самые серьезные опасения вызывает заметное стимулирование старинной болезни всей восточной Церкви, неоднократно побежденной ее собор- ным разумом, но не исчезнувшей. Это скрытый папизм или, как сказал бы богослов, криптопа пизм.

Все епископы равны по благодати и, следова тельно, по своей духовной власти, в силу собст венного апостольского преемства. Архиеписко пы, а затем и патриархи появились лишь для удобства церковного управления, прежде всего для удобства созыва Собора или церковного суда

Часто говорят, что в Церкви нет места демо кратии. Но в Церкви нет места и иной монар хии, кроме монархии Самого Христа. Можн осторожно предположить, что ее устройст включает в себя монархию Господа Бога, арист кратию епископата и демократию церковног народа, пребывающих в согласии. В этом случа Патриарх - лишь символ единства Поместно Церкви и председатель в соборе архиереев.

Однако побочным следствием византийско идеи симфонии Церкви и христианского госуда ства - идеи поистине великой - стало преувел чение роли патриарха в качестве второго (наряд с императором) әлемента симфонии. И в русско практике XVII в. первоиерарх воспринимал как носитель почти что четвертой степени св щенства, высшей, нежели епископская.

Собор 1917-1918 гг., восстановивший патр аршье управление, сделал все возможное, дабы возвращением законного возглавления Помес ной Церкви не вернулась старая болезнь. Но последние годы это случилось: растет число ста ропигальных (изъятых из канонической влас архиереев) монастырей; патриарх освящает хр мы вне территории собственной епархии (где и служить в церкви может только с разрешени местного епископа), рекомендует покинуть сво пост наместнику монастыря в чужой епархии. И вот уже ставропигии "удостоена" Почаевск: лавра (форпост Православия на рубеже униа ской әкспансии), только не патриаршей, а кие ской. А ведь Киев никогда не имел права дар вания ставропигии, епископ Тернопольский к нонически был вправе резко поставить на мес митрополита Киевского. Но что делать, если М сква подает пример.

Установить в Церкви противную ее приро пирамиду власти выгодно только одной вражде ной и Православию, и русской нации силе - бн рократии. Естественно, обеим «ветвям» ее: кә бюрократам от государства, так и бюрократа рясоносным. Чего, с Божией помощью, буде надеяться, не допустят как складывающееся России гражданское общество, так и растуще национальное самосознание.

\section{ЦЕРКОВЬ И НАЦИЯ}

C некоторых пор у нас заговорили о мусул манских государствах бывшего СССР. «Мусул манами п при этом считают людей, принадлеж щих к народам, исторически исповедующим 
ый лам. "Мусульманскими народами" Российской Іа.Федерации - тоже исторически - считают мусульманских татар, башкир, аварцев. Получается 8а так, что русские при коммунистах были безбожниками, а представители других народов - му‘0. сульманами?

В действительности есть мусульмане по этнической культуре и есть православные по этничеа. ской культуре. Православных в Узбекистане куда 10- больше, чем мусульман в Российской Федерации. А страна, где культурно-православные - самая но большая группа, является православной.

Латыши - лютеране, латгальцы - римо-католики. Латышей без латгальцев много меньше, чем русских. Следовательно, Латвия - православное государство. Казахстан - тем более правооли славное: русских там куда больше, чем казахов.

Тут мы вплотную подходим к уже упоминавшейся проблеме нации, к отношениям нации и государства. Церковь, несомненно, превыше нации. Глава ее - Сам Христос. А вот государство, столь же несомненно, ниже нации - государство сотворено людьми. Правда, в этом проявился высокий дар сотворчества, дарованный нам Творцом. И все-таки - людьми.

Нацию, этнос сотворил Господь. Не в наказание ли? Приходит на память вавилонское смешение языков. Однако в русском языке понятия "народ" и "язык" - понятия разные.

Все мы потомки Адама и даже Ноя. Но ведь существуют расы, существуют определенные межрасовые барьеры на физиологическом уровне. Вряд ли у нас есть основания утверждать, что все это явилось результатом вавилонского столпотво. рения. $K$ тому же современная әтнология убеждает нас в том, что история языков развивается совершенно иначе, нежели история этносов. Есть этносы, причем враждебные друг другу, говорящие на одном и том же языке. Например, сербы и хорваты.

Этносы могли, таким образом, существовать и до смешения языков. Апостолы посылаются к народам, в Пятидесятницу как высший дар получают возможность говорить "разными языки", в молитве св. Симеона Богоприимца предвозвещается «свет во откровение языков».

Мы все чувствуем, что существуют неповторимые черты каждого народа. Кстати, и положительные, и отрицательные - с позиций Православия.

Нет русской Церкви, но есть русское Православие, есть русская церковность, несколько отличная, например, от греческой. У каждого народа своя роль и православные византийцы вряд ли получат на Страшном Суде упрек в том, что не выполнили свою... Сколько существовал в истории греко-византийский (ромейский) этнос, сколько Бог дал ему сил, он сохранял империю, Православное Царство. Русские не смогут так ответствовать на Суде. У нас еще есть силы, но мы, получив скипетр из Константинополя, свою роль до конца не исполнили.

С точки зрения православной политики необходимо реабилитировать понятие «национализм", избавив его от зарубежных интерпретаций. Национализм в русском варианте проявляется лишь в том, что дела своей нации касаются русского прежде, а дела других наций - потом. Кстати, в Западной Европе зачастую так этот термин и понимают.

Нам советское владычество навязывало иное. Даже академик Дмитрий Лихачев сказал как-то нелепейшую для человека такой огромной культуры вещь: «Я за национальное, но против националистического". Его можно спросить: «Дмитрий Сергеевич, помилуйте. Как звучит существительное от слова “националистический”? Националист. А от слова "национальный”? Национал? Но такого русского слова нет!». Значит именно от прилагательного "национальный» образуется красивое и честное слово "националист".

Агрессивный национализм, враждебный другим народам, именуется шовинизмом, а превозносящий себя над другими этносами - нацизмом. Когда же своей нации разрешается национализм, а другим запрещается - тогда речь нужно вести о том, что подобные формы для христианина неприемлемы. Вот и все.

Какова альтернатива национализму? Космополитизм - этот «яд всесмешения», как назвал его в прошлом веке К.Н.Леонтьев? Интернационализм? Но сумел ли кто-нибудь доказать его отличие от космополитизма? Впрочем, можно предложить и терпимую формулировку: «интернационализм есть сумма дружелюбных национализмов". Это, кстати, - формула Империи, формула единства наций в общей государственности.

Русских безусловно касаются судьбы восточно-христианских этносов - славян и греков, грузин и осетин, коптов и әфиопов. Но русских касаются и судьбы всех этносов, которые пожелали связать с ними свою жизнь - тех, кто даже не будучи православными, сами выбирают соседство с русскими. Имперский долг тяжел, но он - на циональная традиция. И мы не можем (как и римляне!) отмахнуться небрежно, когда абхаз или гагауз, сету или житель Памира предпочитает жить в России. Все империи на протяжении столетий жили в этой схеме, нарушающей даже вероисповедные различия - малый всегда с большим против среднего, а отношения со "средними" бывают различными.

Итак, "национальное» - это совершенно необходимая часть православного мировоззрения. Тяжкая ошибка многих наших вполне порядочных патриотов в том, что они этого не поняли и остались этатистами (государственниками), не став националистами. 
В России существует опасность национального изоляционизма. В русском народе созрел колоссальный потенциал, не имеющий культурной ориентации. Он может реализоваться как имперский. Это не исключает здорового национализма - не может римлянин не владычествовать над Римом, не может быть России без русских во главе eе! Но если потенциал национального гнева реализуется чисто националистически, тогда имперскому мировоззрению не будет места - русские замкнутся в своих границах и начнут выкидывать мигрантов, подобно тому как пытаются вышвыривать русских со своих территорий крошечные прибалтийские этносы. Третьего не дано!

Как же сохранить свой национализм от соскальзывания в шовинизм? Так же просто, как и многие века назад! Рецепт - православие, православная вера, православная нравственность, православная культура, православная элита, православное почитание народом своей православной элиты.

Высшая иерархия ценностей христианской политики лишь одна - Церковь, Нация, Держава.

\section{ОСНОВЫ ПРАВОСЛАВНОЙ ПОЛИТИКИ}

Есть смысл предложить ряд тезисов, связанных с практической православной политикой.

Первое. Мы живем не в православном и не в русском государстве, хотя в православной и русской стране. Христианам не привыкать строить в подобных условиях свою политику - политику терпимых взаимоотношений с чужими, политику взаимоотношений русских князей, бояр, епископов с золотоордынскими ханами. Для нас драгоценен политический опыт греков и армян в Османской империи, украинцев и белорусов в Речи Посполитой. Там - и наша богатейшая демократическая традиция, сохранившая Православие Западной Руси, и традиция мещанских братств, казачества, интеллектуалов Киевской академии.

Bторое. Русский национализм был ближе всех других в империи к Православию, был столпом Церкви. И в советское время бывали у многих народов национал-большевики (и к власти пришли!); русский же был либо большевиком, либо националистом. Теперь национализм зачастую обретает нехристианский облик. Или же пропаганда стремится выдать за национализм нехристианские тенденции ${ }^{4}$. Это напоминание христианам о национальном долге.

Tретье. Коммунист не может быть христианином. Бывший, покаявшийся, конечно, может. Нераскаявшийся коммунист даже и в церковь входить не смеет! И не потому что коммунисты убили тысячи и тысячи добрых христиан - Господь молился о Своих мучителях - а потому, что коммунисты разрушили великую христианскую Державу, опору Церкви, соблазнили миллионы "малых сих", предали и Церковь, и нацию. Ны- нешних разрушителей Отечества тоже вырасти, коммунисты.

Четвертое. Христианам приходится име дело с политиками и предпринимателями, хоть не православными, но и не враждебными Цер ви. Где критерий допустимости? За кого мож голосовать, когда нет брата своего?

Приемлем только тот политик, который пр нимает идею компенсации. Речь идет прежде в го о компенсации вероисповедной: Церкви дол: но быть возвращено все имущество, христие ское просвещение должно получить права и к териальную базу, позволяющие преодолеть следствия советских гонений, в православн, страну должен вернуться православный кале дарь со всеми праздниками. Речь идет и о ко пенсации национальной: русские должны име реальную возможность восстановить имуще венный потенциал, восстановить в течение ж ни поколения уровень рождаемости, на всей те ритории бывшего Советского Союза должны бы устранены последствия многолетней дискрим нации русских по уровню образованности.

Пятое. Нам необходимы православные и р ские начальники. Церковь учит почтению к в чальнику, который "Божий слуга есть», а системе его назначения. Мы должны приучать в том числе и с амвона, почитать и слушать дє ковного старосту, главу братства, союза при дов, национального вождя и воеводу никак меньше министра, мәра и участкового уполнол ченного.

Шестое. Миряне обязаны защищать церкө нослужителей и учителей. Чеченский народ, имеющий государства, имеет армию, обществ ная организация «Конфедерация народов Кавк за" - армию и секретную службу. Следовательн это армия национальная, вооруженные сил этноса. Следовательно, русские имеют право свою гвардию, православные - на свою.

Седьмое. Православная культурная элита в велика. Тем важнее повседневное воспитание русском человеке безусловного почтения к св ему профессору и учителю. Уважение к ученос - традиция Вселенской Церкви и наша многов ковая национальная традиция, подорванная $p$ волюционными недоучками. Русским нужен интеллигент, а барин - носитель чувства ответс венности за Церковь и нацию. Народ, не ж лающий кормить своего барина, кормит чужог Чем мы три четверти века и занимаемся...

Восьмое. Излюбленная ложь нашего времени это «двойной стандарт», когда нам говорят, ч? можно бомбить Югославию и Ирак, но нелы бомбить Турцию, которая захватила полови Кипра, что нельзя выгонять сектантских ми сионеров из России, но православные храмы Галичине можно захватывать с помощью ом новских дубинок. Лицо, проповедующее подо ный «двойной стандарт», должно быть непр станно обличаемо, как служитель отца лжи. 
Девятое. Христиане Запада - все-таки христиане и остатки христианской совести сохранили. Наш долг непрестанно напоминать им обо всех их прегрешениях перед христианским Востоком от погрома Константинополя в 1204 г. и многовековой униатской агрессии до избиения сербов и выдачи русских казаков Сталину на убой. Застенчивость в разговоре на эту тему напоминает отступничество.

Десятое. Следует трудиться над восстановлением общества, воссозданием плотной социальной среды. Ее разрушали, разоряя деревню, перекидывая нас из города в город, отправляя на "стройки пятилетки". Из нас делали босяков, бомжей, а теперь еще и делают беженцев. Христианин бывает только прихожанином конкретной церкви. И все другие прихожане его знают. А он - их и их детей.

Гражданином России может быть только гражданин Коломны, Ярославля, Вятки..., а не просто "житель". Нас не касается, как наш брат по- стится и молится - это дело Господа Бога, да еще духовника. А вот кто как трудится на благо прихода, братства, всей Церкви, всей нации это нас всех касается. Нас касается, какой предприниматель деньги на храм или православный университет дает, а какой на кришнаитов или последователей Рерихов.

Рецептов воссоздания России множество. Мы не ошибемся, если не нарушим верной иерархии ценностей: сперва Церковь, затем русский народ, а лишь потом - государство.

Господь показал пророку Своему Иезекиилю кости сухие. Забудем национальное - не соберутся кости сухие и не покроются плотью. Забудем православное - не оживут кости наитием Святого Духа. Не забудем - восстанет "Собор мног зело».

${ }^{1}$ Русской Церкви в известном смысле не существует. Есть Вселенская Православная Церковь и есть Поместные церкви - ее отражения в каждой земле и даже в каждой епархии. Поәтому корректнее старое самоназвание Православная Российская Церковь, то есть Вселенская Церковь, действующая на территории России. К этому нужно снова привыкать, пока, наконец, поместный или архиерейский Собор не восстановит исторического наименования.

${ }^{2}$ Ныне наших соотечественников морочат тем, будто головы орла на гербе России смотрят на Восток и на Запад. На деле же, увенчанные коронами, они означают двуединство Церкви и христианской державы, а третий венец - нисхождение небесного благословения на их симфонию. Это - единственно точное геральдическое прочтение.

${ }^{3}$ Полный текст "Основных положений", принятых Священным Собором Православной Российской Церкви 2 декабря 1917 г., см. в Приложении к настоящему изданию (Прим. ред.).

${ }^{4}$ Например, в программе PHE (А.Баркашова) содержится уродливая и страшная неправда безбожия. Но в ней есть и правда (в сравнении с «патриотами-державниками») - правда приоритета нации над государством. В то же время пропагандистская ложь провозглашает демагога-государственника В.Жириновского «нацистом", хотя он даже и не националист. 